\title{
Prawo do nauki. Prawa dziecka-ucznia
}

Najgorzej, gdy szkoła ucieka się do takich metod jak zastraszanie, przemoc czy sztuczny autorytet. Metody te niszczą u uczniów naturalne odruchy, szczerość i wiarę w siebie, czyniąc z nich ludzi uległych.

Albert Einstein

\section{Wprowadzenie}

Prawo do nauki znajduje się w samym centrum problematyki praw kulturalnych. Oznacza prawo każdej jednostki ludzkiej do kształcenia we wszystkich jego postaciach, pośrednio służy prawom człowieka, warunkując ich rozwój i wyposażając jednostkę w możliwości intelektualne warunkujące korzystanie z przysługujących praw ${ }^{1}$.

W odniesieniu do dziecka prawo do nauki łączy się z konstytucyjnym obowiązkiem kształcenia spoczywającym na osobach niepełnoletnich, którego realizacja pozostaje pod nadzorem rodziców oraz organów państwowych. Realizacja obowiązków prawnych nałożonych na jednostkę uzależniona jest od istnienia odpowiednich gwarancji prawnych i pozaprawnych, które umożliwiają ich wypełnienie w zmieniającej się rzeczywistości².

${ }^{1}$ J. Mikosz, Prawo do nauki, w: Prawa człowieka. Model prawny, pod red. R. Wieruszewskiego, Wrocław-Kraków-Warszawa 1991, s. 980.

2 B. Banaszak, Podstawowe obowiazki prawne jednostki, Wrocław 1997, s. 56-57; idem, Ogólne wiadomości o prawach człowieka, w: Prawa i wolności obywatelskie w konstytucji RP, pod red. B. Banaszaka, A. Preisnera, Warszawa 2002, s. 19. 
Przedmiotem niniejszego opracowania jest prawo do nauki ze szczególnym uwzględnieniem praw dziecka-ucznia. Rozważania koncentrują się na ustaleniu istoty, charakteru, zakresu przedmiotowego i podmiotowego prawa do nauki. Przedmiotem analizy są obowiązujące na gruncie prawa polskiego gwarancje prawne jego realizacji, $w$ tym $w$ aspekcie zgodności ze standardami międzynarodowymi. Ze względu na obszerność materii przedmiotem analizy są jedynie wybrane zagadnienia dotyczące prawa dziecka do nauki zawarte $w$ aktach prawa międzynarodowego, w prawie wewnętrznym oraz orzecznictwie sądowym.

\section{Pojęcie nauki i prawa do nauki}

Istota prawa do nauki związana jest $\mathrm{z}$ naturalną potrzebą jednostki ludzkiej do zdobywania wiedzy, poznawania tego, co zostało już odkryte, a także poszukiwania tego, co nowe, nieznane, wymagające wyjaśnienia $^{3}$. Zdaniem P. Bały ${ }^{4}$ prawo do nauki jest jednym $z$ najważniejszych praw człowieka definiowanym nierzadko przez jego rozumną naturę. Powinno być rozumiane jako zapewnienie przez państwo nieskrępowanej możliwości uzyskania dostępu do wykształcenia dla szerokiej grupy osób. Pozostaje w ścisłej relacji z obowiązkiem nauki, a w odniesieniu do osób starszych wolne jest od obligatoryjności, pozostawiając im możliwość decydowania zarówno o jej dalszym pobieraniu, jak i kierunku kształcenia ${ }^{5}$. Tradycyjnie prawo do nauki zaliczane jest do praw o charakterze kulturalnym, jednak niektórzy autorzy dopatrują się w nim elementów ekonomicznych ${ }^{6}$. Zdaniem J. Mikosza na prawo do nauki składają się: prawo do nauczania i kształcenia oraz system instytucji publicznych i niepublicznych mających służyć jego realizacji ${ }^{7}$.

Według UNESCO nauka obejmuje cały proces życia społecznego realizowany za pomocą środków, którymi jednostki i grupy społeczne uczą się świadomie rozwijać dla siebie i dla dobra wspólnoty narodowej i międzynarodowej pełnię swoich osobistych możliwości, postaw

${ }^{3}$ J. Oniszczuk, Wolności i prawa socjalne oraz orzecznictwo konstytucyjne, Warszawa 2005, s. 291.

${ }^{4}$ P. Bała, Konstytucyjne prawo do nauki a polski system oświaty, Warszawa 2009, s. 213, 229-230.

${ }^{5}$ L. Garlicki, Komentarz do art. 70, w: Konstytucja Rzeczypospolitej Polskiej. Komentarz, t. 3, pod red. L. Garlickiego, Warszawa 2003, s. 4.

${ }^{6}$ B. Banaszak, Konstytucja Rzeczypospolitej Polskiej..., s. 415.

${ }^{7}$ J. Mikosz, op. cit., s. 983. 
i uzdolnień oraz wiedzy ${ }^{8}$. Z definicją tą koresponduje pogląd A. Łopatki, zgodnie z którym prawa do nauki nie można utożsamiać i zawężać jedynie do procesu nauczania w szkołach ${ }^{9}$. Pod pojęciem nauczania należy rozumieć nie tylko merytoryczne przekazywanie wiedzy, ale również odpowiedni system szkół o charakterze trójstopniowym z możliwością wprowadzania pomiędzy kolejnymi etapami edukacyjnymi pośrednich systemów nauczania ${ }^{10}$. Z kolei Europejski Trybunał Praw Człowieka dokonuje rozróżnienia pojęć "edukacja” i "nauczanie”, wskazując, że edukacja jest pojęciem szerszym od nauczania, które jest szczególną formą przekazywania wiedzy i rozwoju umysłowego ${ }^{11}$. Na uwagę zasługuje również pogląd wyrażony przez T. Jasudowicza, zgodnie z którym prawo do nauki nie jest tylko prostym wyposażeniem ucznia w wiedzę. Nauczanie powinno bowiem pokazać każdemu człowiekowi drogę do pogłębionego człowieczeństwa, wartościowego życia w rodzinie, społeczeństwie, ojczyźnie ${ }^{12}$.

\section{Prawo do nauki w prawie międzynarodowym}

Pierwszym dokumentem, w którym proklamowane zostało prawo do nauki, była Powszechna Deklaracja Praw Człowieka, uchwalona na trzeciej Sesji Ogólnego Zgromadzenia ONZ obradującej w Paryżu w dniu 10 grudnia 1948 r. Zgodnie z art. 26 Deklaracji celem nauczania jest pełny rozwój osobowości ludzkiej i ugruntowanie poszanowania praw człowieka i podstawowych wolności. Krzewi ono zrozumienie, tolerancję i przyjaźń między wszystkimi narodami, grupami rasowymi lub religijnymi, popiera działalność Organizacji Narodów Zjednoczonych zmierzającą do utrzymania pokoju.

W Deklaracji uznano prawo każdego człowieka do bezpłatnej, przynajmniej na stopniu podstawowym, nauki, wskazując, że nauka podstawowa jest obowiązkowa. Oświata techniczna i zawodowa, w myśl

${ }^{8}$ UNESCO Recommendation Concerning Education for International Understanding, Co-operation and Peace and Education Relating to Human Rights and Fundamental Freedoms. Zalecenie zostało przyjęte na XVIII Konferencji Genewskiej UNESCO w 1974 r.

${ }^{9}$ A. Łopatka, Dziecko. Jego prawa człowieka, Warszawa 2000, s. 100 i n.

${ }^{10}$ Konstytucje Rzeczypospolitej oraz komentarz do Konstytucji RP z 1997 roku, pod red. J. Bocia, Wrocław 1998, s. 129.

11 A. Nowicki, Europejski Trybunał Praw Człowieka. Orzeczenia, t. 2, Kraków 2002, s. 1431.

12 T. Jasudowicz, Prawo do nauki, w: B. Gronowska, T. Jasudowicz, M. Balcerzak, M. Lubiszewski, R. Mizerski, Prawa człowieka i ich ochrona, Toruń 2005, s. 381-382. 
postanowień Deklaracji, jest powszechnie dostępna, a studia wyższe są dostępne dla wszystkich na zasadzie równości w zależności od zalet osobistych. Deklaracja przyznała również rodzicom prawo pierwszeństwa w wyborze nauczania, które ma być dane ich dzieciom.

Dzięki zamieszczeniu prawa do nauki w Międzynarodowym Pakcie Praw Gospodarczych, Społecznych i Kulturalnych otwartym do podpisu w Nowym Jorku dnia 19 grudnia 1966 r. $^{13}$, prawo do nauki zyskało charakter obowiązującej normy prawnomiędzynarodowej. W art. 13 Paktu nałożono na państwa-strony Paktu obowiązek uznania prawa każdego do nauki. Zgodnie z Paktem nauczanie powinno zmierzać do pełnego rozwoju osobowości i poczucia godności ludzkiej i umacniać poszanowanie praw człowieka i podstawowych wolności, a nauka powinna umożliwiać wszystkim efektywny udział w wolnym społeczeństwie, rozwijać zrozumienie, tolerancję i przyjaźń między wszystkimi narodami i wszystkimi grupami rasowymi, etnicznymi lub religijnymi, jak również popierać działalność Organizacji Narodów Zjednoczonych na rzecz utrzymania pokoju. W celu pełnej realizacji prawa do nauki na państwa-strony nałożono obowiązek zagwarantowania, że:

- nauczanie podstawowe będzie obowiązkowe, bezpłatne i dostępne dla wszystkich;

- nauczanie średnie w jego różnych formach, włączając w to średnie nauczanie techniczne i zawodowe, będzie powszechnie dostępne dla wszystkich w wyniku zastosowania wszelkich odpowiednich środków, w szczególności stopniowego wprowadzania bezpłatnej nauki;

- nauczanie wyższe będzie w równym stopniu dostępne dla wszystkich na podstawie kryterium zdolności, w wyniku zastosowania wszystkich odpowiednich środków, w szczególności stopniowego wprowadzania bezpłatnej nauki;

- nauczanie elementarne będzie popierane lub rozwijane w możliwie największym stopniu dla osób, które nie otrzymały lub nie ukończyły pełnego wykształcenia podstawowego;

- rozwój systemu szkół wszystkich stopni będzie aktywnie kontynuowany oraz będzie ustanowiony odpowiedni system stypendiów, a warunki materialne personelu nauczającego będą stale poprawiane.

Jednocześnie Pakt nałożył na państwa-strony obowiązek poszanowania wolności rodziców lub w odpowiednich przypadkach opiekunów prawnych, wyboru dla swych dzieci szkół innych niż szkoły założone

${ }^{13}$ Dz.U. 1977 Nr 38, poz. 169. 
przez władze publiczne, ale odpowiadających minimalnym wymaganiom w zakresie nauczania, jakie mogą być ustalone lub zatwierdzone przez państwo, jak również zapewnienia swym dzieciom wychowania religijnego i moralnego zgodnie $\mathrm{z}$ własnymi przekonaniami.

Prawo do nauki znalazło również swoje miejsce w Konwencji o Ochronie Praw Człowieka i Podstawowych Wolności przyjętej przez Radę Europy 4 listopada 1950 r. w Rzymie. Zostało umieszczone w art. 2 protokołu dodatkowego do Konwencji. Zgodnie z jego treścią nikt nie może być pozbawiony prawa do nauki. Wykonując swoje funkcje w dziedzinie wychowania i nauczania, państwo uznaje prawo rodziców do zapewnienia tego wychowania i nauczania zgodnie $\mathrm{z}$ ich własnymi przekonaniami religijnymi i filozoficznymi. Negatywne sformułowanie artykułu "nikt nie może być pozbawiony” oraz konstrukcja językowa wskazuja, że Konwencja ujmuje prawo do nauki przede wszystkim jako prawo do swobody edukacji ${ }^{14}$.

Zgodnie z zasadą 7 Deklaracji Praw Dziecka uchwalonej 20 listopada 1959 r. dziecko ma prawo do nauki, która jest bezpłatna i obowiązkowa, przynajmniej w zakresie szkoły podstawowej. Dziecko powinno otrzymać takie wychowanie, które podnosi jego kulturę ogólną i umożliwia $\mathrm{mu}, \mathrm{w}$ warunkach równych szans, rozwinięcie swych zdolności, wyrobienie zdrowego rozsądku oraz poczucia odpowiedzialności moralnej i społecznej, a także stanie się pożyteczną jednostką społeczeństwa. Osoby odpowiedzialne za wychowanie dziecka i kierowanie nim powinny mieć na względzie jego dobro, a odpowiedzialność ta spada przede wszystkim na rodziców. Społeczeństwo i władze państwowe powinny natomiast ułatwić korzystanie $\mathrm{z}$ tego prawa.

Zagwarantowanie podobnych możliwości w dziedzinie wykształcenia bez jakichkolwiek różnic dyskryminacyjnych przy jednoczesnym zapewnieniu związku z własną narodową kulturą jest warunkiem koniecznym do pełnego rozwoju jednostki oraz korzystania przez nią w pełni z przysługujących jej praw.

Wyrazem walki oraz sprzeciwu przeciwko istniejącym, również na polu oświatowym, przejawom dyskryminacji było uchwalenie 14 grudnia 1960 r. Konwencji i zaleceń UNESCO w sprawie zwalczania dyskryminacji w dziedzinie oświaty ${ }^{15}$. W rozumieniu Konwencji „dyskryminacja" oznacza wszelkie wyróżnianie, wykluczanie, ograniczanie

${ }^{14}$ M. Nowicki, Wokół Konwencji Europejskiej. Komentarz do Europejskiej Konwencji Praw Człowieka, Warszawa 2017, s. 876.

${ }^{15}$ Dz.U. 1964 Nr 40, poz. 268. 
lub uprzywilejowanie ze względu na rasę, kolor skóry, płeć, język, wyznanie, przekonania polityczne lub jakiekolwiek inne, narodowość lub pochodzenie społeczne, sytuację materialną lub urodzenie, które ma na celu albo którego skutkiem jest przekreślenie lub naruszenie zasady jednakowego traktowania w dziedzinie oświaty. W celu wyeliminowania bądź zapobieżenia dyskryminacji Konwencja zobowiązuje państwa-strony m.in. do uchylenia wszelkich przepisów ustawowych lub zarządzeń administracyjnych oraz zaprzestania wszelkich praktyk administracyjnych o charakterze dyskryminacyjnym w dziedzinie oświaty, jak również umożliwienia cudzoziemcom zamieszkującym terytorium danego kraju takiego samego dostępu do oświaty jak własnym obywatelom. W art. 9 Konwencji wykluczono możliwość złożenia do niej jakichkolwiek zastrzeżeń.

Prawu dziecka do nauki dwa obszerne artykuły poświęca przyjęta przez Zgromadzenie Ogólne Narodów Zjednoczonych 20 listopada 1989 r. Konwencja o Prawach Dziecka ${ }^{16}$, określana mianem światowej konstytucji praw dziecka. W artykule 29 Konwencji wskazano, że nauka dziecka ma być ukierunkowana na rozwijanie w jak najpełniejszym zakresie osobowości, talentów oraz zdolności umysłowych i fizycznych dziecka. Ma służyć rozwijaniu szacunku dla praw człowieka i podstawowych swobód oraz dla zasad zawartych w Karcie Narodów Zjednoczonych, rozwijaniu szacunku dla rodziców dziecka, jego tożsamości kulturowej, języka i wartości, dla wartości narodowych kraju, w którym mieszka dziecko, kraju, z którego dziecko pochodzi, jak i innych kultur, przygotowaniu dziecka do odpowiedzialnego życia w wolnym społeczeństwie, w duchu zrozumienia, pokoju, tolerancji, równowartości płci oraz przyjaźni pomiędzy wszystkimi narodami, grupami etnicznymi, narodowymi i religijnymi oraz osobami rdzennego pochodzenia, jak również rozwijaniu poszanowania środowiska naturalnego.

W Konwencji podkreślono wolność osób fizycznych i ciał zbiorowych do zakładania i prowadzenia instytucji oświatowych, wskazując, że wymienione cele nauczania winny być realizowane zarówno w szkołach $\mathrm{i}$ instytucjach publicznych, jak i prywatnych, z zastrzeżeniem przestrzegania celów określonych w Konwencji, jak również minimalnych standardów określonych przez państwo. W Konwencji uznano prawo dziecka do nauki na zasadzie równych szans ${ }^{17}$.

${ }^{16}$ Dz.U. 1991 Nr 120, poz. 526.

${ }^{17}$ M. Czaja, Ochrona rozwoju dziecka przed zagrożeniami w aspekcie prawa międzynarodowego, europejskiego i krajowego, Warszawa 2016, s. 31. 
W celu realizowania tego prawa Konwencja nakłada na państwa-strony m.in. zobowiązanie do uczynienia nauczania podstawowego obowiązkowym i bezpłatnym dla wszystkich, popierania rozwoju różnorodnych form szkolnictwa średniego, zarówno ogólnokształcącego, jak i zawodowego, uczynienia go dostępnym dla każdego dziecka oraz podjęcia odpowiednich kroków, takich jak wprowadzenie bezpłatnego nauczania oraz udzielanie $\mathrm{w}$ razie potrzeby pomocy finansowej, podjęcia kroków na rzecz zapewnienia regularnego uczęszczania do szkół oraz zmniejszenia wskaźnika porzucania nauki.

Państwa-strony, w myśl postanowień Konwencji, mają również podejmować wszelkie właściwe działania, aby dyscyplina szkolna była wprowadzana zgodnie z ludzką godnością dziecka i zgodnie z Konwencja, jak również popierać i rozwijać międzynarodową współpracę w dziedzinie oświaty, w szczególności w celu przyczyniania się do zlikwidowania ignorancji i analfabetyzmu na świecie, oraz ułatwienia dostępu do wiedzy naukowo-technicznej i nowoczesnych metod nauczania, ze szczególnym uwzględnieniem potrzeb krajów rozwijających się.

Prawo do nauki znalazło się również w Karcie Podstawowych Praw Unii Europejskiej ${ }^{18}$. Zgodnie z jej art. 14 każdy ma prawo do nauki, w tym prawo do nieodpłatnej nauki obowiązkowej oraz dostępu do szkolenia zawodowego i ustawicznego. W Karcie podkreślono również prawo rodziców do zapewnienia wychowania i nauczania dzieci zgodnie z własnymi przekonaniami religijnymi, filozoficznymi oraz zgodnie z ustawami krajowymi regulującymi korzystanie z takiej wolności i prawa, jak również wolność tworzenia placówek oświatowych z właściwym poszanowaniem demokratycznych zasad.

Potrzeba kodyfikacji praw osób niepełnosprawnych, które to prawa zamieszczane były w rozmaitych aktach różnej rangi, i nadania im prawnie wiążącego charakteru była przyczyną uchwalenia w dniu 13 grudnia 2006 r. przez Zgromadzenie Ogólne Narodów Zjednoczonych Konwencji Praw Osób Niepełnosprawnych ${ }^{19}$. Prawu do edukacji poświęcony jest art. 24 Konwencji. Zgodnie z jego treścią państwa-strony uznają prawo osób niepełnosprawnych do edukacji bez jakiejkolwiek dyskryminacji i na zasadach równości. System edukacji integracyjnej na wszystkich etapach edukacyjnych oraz kształcenia ustawicznego winien być, w założeniu Konwencji, ukierunkowany na: pełny rozwój

\footnotetext{
${ }^{18}$ Dz.Urz. UE C 303 z 14 XII 2007 r., s. 1.

${ }^{19}$ Dz.U. 2012, poz. 1169.
} 
ludzkiego potencjału, poczucia godności i własnej wartości, rozwój osobowości, talentów i kreatywności, jak również rozwój intelektualny i fizyczny osób niepełnosprawnych oraz umożliwienie im efektywnego uczestnictwa w wolnym społeczeństwie. Gwarancją realizacji prawa osób niepełnosprawnych do edukacji mają być spoczywające na państwach-stronach Konwencji obowiązki zapewnienia, aby m.in.:

- osoby niepełnosprawne nie były wykluczane z powszechnego systemu edukacyjnego ze względu na swoją niepełnosprawność (dzieci niepełnosprawne nie zostaną wykluczone z bezpłatnej i obowiązkowej edukacji podstawowej i średniej ze względu na swoją niepełnosprawność;

- osoby niepełnosprawne miały dostęp do bezpłatnej podstawowej i średniej edukacji integracyjnej na dobrym poziomie, na zasadzie równych szans;

- wprowadzone zostały racjonalne dostosowania do szczególnych potrzeb osób niepełnosprawnych;

- osoby niepełnosprawne otrzymały wsparcie w ramach powszechnego systemu edukacyjnego. Prawo do nauki było również przedmiotem uwagi Europejskiego Trybunału Praw Człowieka w Strasburgu.

W wyrokach: z dnia 10 listopada 2005 r. (sygn. 44774/98), z dnia 15 czerwca 2010 r. (sygn. 7710/02) oraz z dnia 21 czerwca 2011 r. (sygn. 5335/05) Trybunał wskazał, że prawo do nauki jest w demokratycznym społeczeństwie niezbędne do korzystania z praw człowieka. Nie ma wątpliwości, iż jest nim objęta edukacja na poziomie średnim, trudno również wyobrazić sobie, aby nie była nim objęta edukacja na poziomie wyższym. Szczególne znaczenie ma spoczywający na państwie obowiązek ochrony dzieci uczących się na poziomie edukacji podstawowej. Zdrowie i dobro uczniów, w tym ochrona przed nadużyciami seksualnymi, jest szczególnym obowiązkiem władz szkolnych. Nieodłączną częścią prawa do nauki jest prawo dostępu do istniejących instytucji edukacyjnych. Interpretacja taka, zdaniem Trybunału, nie oznacza nałożenia na państwa nowych obowiązków, ale wynika z interpretacji przepisu oraz celu i przedmiotu Konwencji. Nie zobowiązuje on do tworzenia instytucji akademickich, ale w przypadku ich istnienia nakłada na państwo obowiązek zapewniania rzeczywistego dostępu do nich. W wyroku z dnia 27 maja 2014 r. (sygn. 16032/07) Trybunał wskazał, że państwo nie ma obowiązku zapewnienia możliwości kontynuowania nauki w więzieniu w każdych okolicznościach. Jeżeli jednak taka możliwość istnieje, nie można w sposób arbitralny i nieuzasadniony jej ograniczać. W wyroku z dnia 9 lipca 2013 r. (sygn. 37222/04) Trybunał 
wyraził pogląd, iż uniemożliwienie wstępu na studia osobom, które zdały egzamin wstępny, wykazując wysoki poziom przygotowania, nie może być uznane za pozbawienie prawa do nauki tych, którzy go nie zdali. Swoboda państwa w regulacji dostępu do studiów wyższych winna opierać się na kwalifikacjach kandydatów, nie może jednak oznaczać ich oceny z naruszeniem zasady równości i sprawiedliwości, gdyż prowadzi to do zanegowania samej istoty prawa do nauki.

W wyroku z dnia 6 października 2015 r. (sygn. 37991/12) przedmiotem rozważań Trybunału było prawo do nauki oraz zwłoka w przywróceniu dzieci do szkoły po diagnozie lekarskiej stwierdzającej ich dobry stan zdrowia.

Przyznając rację skarżącym, w uzasadnieniu rozstrzygnięcia Trybunał wskazał, że prawo do nauki, w rozumieniu pierwszego zdania art. 2 Protokołu nr 1 do Konwencji, gwarantuje każdej osobie podlegającej jurysdykcji państwa prawo dostępu do placówek edukacyjnych istniejących w danym momencie, a dostęp do takich placówek stanowi kształtujący element tego prawa podstawowego. Prawo to nie ma charakteru bezwzględnego, z samej natury wymaga uregulowania przez państwo i może podlegać ograniczeniom. Stąd też, zdaniem Trybunału, przepisy regulujące funkcjonowanie placówek edukacyjnych mogą różnić się w czasie w zależności m.in. od potrzeb i zasobów społecznych, jak i charakteru nauczania na różnych poziomach, a organy władzy krajowej cieszą się w tej mierze pewnym marginesem uznania. Stosowane ograniczenia mogą być wprowadzane z poszanowaniem wymogów Konwencji, nie mogą jednak redukować prawa, którego dotyczą, w stopniu upośledzającym istotę tego prawa.

W kolejnym wyroku z dnia 16 marca 2010 r. (sygn. 15766/03) przedmiotem rozważań Europejskiego Trybunału Praw Człowieka było prawo do nauki i zakaz dyskryminacji ze względu na narodowość w kontekście prawa mniejszości narodowych.

W uzasadnieniu swojego rozstrzygnięcia Trybunał wskazał, że prawo dostępu do istniejących w danym czasie instytucji edukacyjnych stanowi jedynie część prawa do nauki. Aby prawo to było skuteczne, konieczne jest m.in., by osoba, która jest jego beneficjentem, miała możliwość czerpania korzyści z otrzymanego wykształcenia, czyli innymi słowy, prawa do uzyskania, zgodnie z przepisami obowiązującymi w każdym państwie, w takiej czy innej formie wykształcenia.

Różnica w traktowaniu, zdaniem Trybunału, jest dyskryminująca, jeżeli nie ma obiektywnego i rozsądnego uzasadnienia, czyli jeżeli 
nie realizuje się uzasadnionego prawnie celu lub jeżeli nie zachodzi rozsądna relacja proporcjonalności pomiędzy stosowanymi środkami oraz celem, który miał zostać zrealizowany.

Przedmiotem rozważań Europejskiego Trybunału Praw Człowieka w decyzji z dnia 15 lutego 2001 r. (sygn. 42393/98) była wolność wyznania w aspekcie wprowadzonego przez władze krajowe zakazu noszenia chusty islamskiej w szkole przez nauczycielkę nauczania początkowego ${ }^{20}$. Trybunał nie przyznał racji skarżącej, a w uzasadnieniu swojego rozstrzygnięcia wskazał, że trudno jest ocenić wpływ tak silnej zewnętrznej oznaki (religijnej), jaką jest noszenie chusty, na wolność sumienia i wyznania małych dzieci. Skarżąca nauczała klasę składająca się z dzieci pomiędzy 4. a 8. rokiem życia, a tym samym jej uczniowie znajdowali się $w$ wieku, kiedy dzieci zadają wiele pytań i kiedy łatwiej ulegają wpływom niż w przypadku starszych uczniów. Nie można więc w tych okolicznościach zaprzeczyć istnieniu wpływów o charakterze prozelitycznym, jakie może wywierać noszenie chusty, skoro nakaz ten stanowi zalecenie prawa koranicznego, które - zdaniem krajowego sądu federalnego - trudno jest pogodzić z zasadą równości płci. Trudne także wydaje się pogodzenie noszenia islamskiej chusty z przesłaniem tolerancji, poszanowaniem innych, a przede wszystkim z równością i zakazem dyskryminacji, które w ustroju demokratycznym każdy nauczyciel powinien przekazywać swoim uczniom.

Tym samym, równoważąc prawo nauczycielki do manifestowania swego wyznania $z$ ochroną ucznia poprzez gwarantowanie pokoju religijnego, Trybunał stwierdził, że w okolicznościach rozpoznawanej sprawy oraz wobec młodego wieku dzieci, za które skarżąca była odpowiedzialna jako przedstawicielka państwa, władze krajowe nie przekroczyły przysługującego im marginesu uznania, a tym samym zastosowany środek nie był nierozsądny.

Przedmiotem rozważań Trybunału wielokrotnie było również prawo rodziców do wychowania i nauczania dzieci zgodnie z własnymi przekonaniami w kontekście prawa dziecka do nauki. W wyrokach: $\mathrm{z}$ dnia 9 października 2007 r. (sygn. 1448/04), z dnia 16 września 2014 r. (sygn. 21163/11) oraz z dnia 26 kwietnia 2016 r. (sygn. 62649/10) Trybunał wskazał, że sformułowanie zdania 2 Protokołu nr 1 do Konwencji wymaga od państwa dbałości o to, by informacje oraz wiedza z programów

${ }^{20}$ Zob. też I.C. Kamiński, Islamska chusta i zasłony twarzy u kobiet w orzecznictwie Europejskiego Trybunału Praw Człowieka w Strasburgu, „Problemy Współczesnego Prawa Międzynarodowego, Europejskiego i Porównawczego" 2013, t. 11. 
szkolnych przedstawiane były obiektywnie, w sposób krytyczny i w pluralistycznym ujęciu. Odnosi się to także do sytuacji wprowadzenia nauki religii do programu szkolnego. Niezależnie od możliwości zwolnienia z zajęć religii rodzice mają prawo oczekiwać jej nauczania w sposób spełniający kryteria obiektywności i pluralizmu, z poszanowaniem ich przekonań religijnych i filozoficznych.

W wyroku z dnia 23 lutego 2016 r. (sygn. 51500/08) Trybunał zwrócił uwagę na szczególne potrzeby dzieci niepełnosprawnych. Wskazał, że każde dziecko ma swoje własne potrzeby pedagogiczne, a okoliczność ta jest szczególnie istotna w przypadku dzieci z niepełnosprawnościami. W sferze edukacji rozsądne dostosowania mogą przybrać różne formy zarówno materialne, jak i niematerialne, pedagogiczne lub organizacyjne. W rozpoznawanej sprawie organy władzy krajowej nie podjęły żadnej próby zidentyfikowania potrzeb skarżącej, sprecyzowania, w jakim zakresie jej ślepota mogła stanowić przeszkodę przy uczęszczaniu do akademii muzycznej, nie podjęły również chociażby próby poczynienia odpowiednich dostosowań pozwalających na zaspokojenie potrzeb edukacyjnych skarżącej. Odmowa przyjęcia skarżącej do akademii muzycznej opierała się wyłącznie na okoliczności, że jest ona niewidoma. Taka odmowa, bez obiektywnego i rozsądnego uzasadnienia, wyłącznie ze względu na niepełnosprawność stanowi naruszenie art. 14 Konwencji w związku z art. 2 Protokołu nr 1.

\section{Regulacja konstytucyjna prawa do nauki}

Ogólne zasady i gwarancje realizacji prawa do nauki sformułowane zostały w ustawie zasadniczej. Zgodnie z regulacją art. 70 Konstytucji Rzeczypospolitej ${ }^{21}$

każdy ma prawo do nauki. Nauka do 18. roku życia jest obowiązkowa. Sposób wykonywania obowiązku szkolnego określa ustawa. Nauka w szkołach publicznych jest bezpłatna. Ustawa może dopuścić świadczenie niektórych usług edukacyjnych przez publiczne szkoły wyższe za odpłatnością. Rodzice mają wolność wyboru dla swoich dzieci szkół innych niż publiczne. Obywatele i instytucje mają prawo zakładania szkół podstawowych, ponadpodstawowych i wyższych oraz zakładów wychowawczych. Warunki zakładania i działalności szkół niepublicznych oraz udziału władz publicznych w ich finansowaniu,

${ }^{21}$ Konstytucja Rzeczypospolitej Polskiej z dnia 2 IV 1997 r. (Dz.U. Nr 78, poz. 483 ze zm.), dalej „Konstytucja RP” lub „Konstytucja”. 
a także zasady nadzoru pedagogicznego nad szkołami i zakładami wychowawczymi określa ustawa.

Władze publiczne zapewniają obywatelom powszechny i równy dostęp do wykształcenia. W tym celu tworzą i wspierają systemy indywidualnej pomocy finansowej i organizacyjnej dla uczniów i studentów. Warunki udzielania pomocy określa ustawa.

Zapewnia się autonomię szkół wyższych na zasadach określonych w ustawie.

Prawo do nauki zostało umieszczone w rozdziale II Konstytucji poświęconym prawom ekonomicznym, socjalnym i kulturalnym. Najczęściej utożsamiane jest z prawem kulturalnym, chociaż niektórzy komentatorzy dopatrują się w nim elementów prawa ekonomicznego ${ }^{22}$. Powszechnie utożsamia się je z prawem do wykształcenia - prawem do korzystania z usług edukacyjnych placówek oświatowych ${ }^{23}$. Prawo do nauki w świetle postanowień konstytucyjnych jest prawem człowieka, a możliwość korzystania z niego winni mieć wszyscy przebywający na terytorium Rzeczypospolitej ${ }^{24}$. Stanowi swoiste odrębne prawo podmiotowe, odnosi się do każdego i z natury rzeczy może dotyczyć jedynie osoby fizycznej ${ }^{25}$. Prawo do nauki winno być postrzegane zarówno w kategoriach dobra i wartości indywidualnej, jak i ważnego, podstawowego dobra społecznego. Urzeczywistnienie prawa do nauki jest nie tyle jakimś szczególnym przywilejem współczesnego człowieka, ile stanowi nieodzowny warunek rozwoju społeczeństwa i jednocześnie pełnego uczestnictwa jednostki w życiu społecznym. Jego organizacja, dostępność, powszechność stają się jednym z najważniejszych zadań państwa i władzy publicznej. Celem i istotą tego prawa jest bowiem stworzenie jednostce realnych szans kształcenia na różnych poziomach edukacyjnych ${ }^{26}$.

$Z$ treści przepisu art. 70 ust. 1 Konstytucji RP w sposób jasny i niebudzący wątpliwości wynika, że prawo do nauki jest prawem każdego obywatela niezależnie od jakichkolwiek jego cech, w tym stanu zdrowia.

${ }^{22}$ Zob. M. Golowkin-Hudala, Rodzina jako wartość chroniona Konstytucji na tle europejskich standardów ochrony praw człowieka, w: Polska wobec europejskich standardów praw człowieka, pod red. T. Jasudowicza, Toruń 2001, s. 89; M. Jabłoński, S. Jarosz-Żukowska, Prawo konstytucyjne w formie pytań i odpowiedzi, Wrocław 2003, s. 227.

${ }^{23}$ M. Królikowski, K. Szczucki, Uwagi wstępne do art. 70 ust. 1, 2 i 4 Konstytucji $R P$, w: Konstytucja RP, t. 1: Komentarz do art. 1-86, pod red. M. Safiana, L. Boska, Warszawa 2016, s. 1575.

${ }^{24}$ O. Rudak, Prawo do nauki, w: Prawa i wolności obywatelskie..., s. 493.

${ }^{25}$ L. Garlicki, Komentarz do art. 70, s. 3.

26 Tak Trybunał Konstytucyjny (TK) w wyroku z 8 XI 2000 r., sygn. SK 18/99, Orzecznictwo Trybunału Konstytucyjnego Zbiór Urzędowy (OTK ZU) 2000, nr 7, poz. 258. 
W konsekwencji Konstytucja RP dopuszcza możliwość kształcenia się osób chorych, pozostawiając decyzję co do wpływu trudów nauki na ich kondycję zdrowotną im samym ${ }^{27}$.

Prawo do nauki wiąże się z nałożonym konstytucyjnie obowiązkiem nauki i obowiązkiem szkolnym. Treścią obowiązku nauki jest uczestniczenie każdego podlegającego prawu RP w zajęciach szkolnych w zakresie i czasie przewidzianych prawem ${ }^{28}$. Od tej zasady ustawa zasadnicza nie przewiduje wyjątków. Nie jest zatem dopuszczalne powoływanie się osób wykonujących władzę rodzicielską na prawo do wychowania dziecka zgodnie $z$ własnymi przekonaniami w sytuacji, kiedy nie uznaja oni wiedzy przekazywanej przez szkołę. Prawo dziecka do uzyskania wykształcenia jest prawem wyższym niż prawo rodziców do kierowania dzieckiem, które doznaje ograniczeń i nie ma charakteru bezwzględnego. W sytuacji kolizji z dobrze rozumianym dobrem dziecka musi ustąpić. Konstytucja pozostawia rodzicom możliwość dokonania wyboru, czy edukacja dziecka będzie miała miejsce w placówce publicznej czy też niepublicznej (podstawowej, ponadpodstawowej).

Warunki powstawania, działania, jak również nadzoru pedagogicznego nad placówkami edukacyjnymi o charakterze niepublicznym określa ustawa, co oznacza, że w zakresie ich tworzenia i funkcjonowania nie ma dowolności. Obowiązek nauki w odniesieniu do osób, które nie ukończyły 18. roku życia ma charakter administracyjnoprawny, a konsekwencje związane z jego niewykonaniem ponosić będą osoby, którym przysługuje władza rodzicielska (rodzice, opiekunowie prawni). W odniesieniu do osób małoletnich nierealizujących obowiązku nauki mogą być stosowane sankcje wychowawcze ${ }^{29}$. Spoczywająca na rodzicach powinność i odpowiedzialność za ukierunkowanie kształcenia dziecka do 18. roku życia nie tylko implikuje określone obowiązki, ale również uprawnia ich do wystapienia w imieniu dziecka $\mathrm{z}$ roszczeniem w sytuacji niezapewnienia przez władze publiczne warunków do realizacji prawa i obowiązku nauki.

Konstytucja gwarantuje bezpłatność nauki w szkołach publicznych, przenosząc ciężar wykształcenia młodego pokolenia na państwo ${ }^{30}$. Zasada bezpłatności ma charakter bezwzględny w odniesieniu

${ }^{27}$ Tak Wojewódzki Sąd Administracyjny w Bydgoszczy w wyroku z 8 IX 2010 r., sygn. II SA/Bd 418/10, LEX nr 752059.

${ }^{28}$ B. Banaszak, Konstytucja Rzeczypospolitej Polskiej..., s. 415.

${ }^{29}$ Konstytucje..., s. 132.

${ }^{30}$ W. Skrzydło, Konstytucja Rzeczypospolitej Polskiej. Komentarz, Kraków 1998, s. 68. 
do publicznych szkół podstawowych, zawodowych i średnich. Szkoły wyższe mogą świadczyć niektóre usługi edukacyjne za odpłatnością.

Zasada bezpłatności nauczania ma, oprócz gwarantowanego konstytucyjnie powszechnego i równego dostępu do wykształcenia, czemu ma służyć pomoc finansowa i organizacyjna ze strony państwa (art. 70 ust. 4 Konstytucji RP), za zadanie minimalizowanie różnic $w$ dostępie do edukacji osób znajdujących się w trudnej sytuacji materialnej. Pomoc ze strony państwa winna mieć charakter zarówno finansowy (przyznawanie świadczeń pieniężnych bezpośrednio osobom uprawnionym), jak i organizacyjny (zapewnienie warunków do pobierania nauki). W doktrynie przyjmuje się, że winna mieć ona charakter indywidualny i być skierowana bezpośrednio do osób zainteresowanych, a nie instytucji świadczących naukę. Prawo do uzyskania pomocy państwa wyrównującej dostęp do edukacji ma ze swojej istoty charakter indywidualny jego podmiotem jest konkretna osoba, a nie instytucja, która sprawuje nad nią opiekę czy też świadczy usługi edukacyjne ${ }^{31}$.

Pierwotnie Trybunał Konstytucyjny dokonywał dosyć wąskiej wykładni art. 70 ust. 4 Konstytucji RP, podkreślając gwarancyjną funkcję tego przepisu ${ }^{32}$. Jednak w wyroku z 26 kwietnia 2004 r. $^{33}$ uznał, że od wejścia w życie Konstytucji z 1997 r. można mówić o istnieniu konstytucyjnego prawa podmiotowego - „prawa do uzyskania pomocy finansowej ze strony władz publicznych w zakresie gwarantującym powszechność i równość dostępu do wykształcenia". Pogląd ten został rozwinięty w wyroku z 16 stycznia 2007 r. ${ }^{34}$, w którym Trybunał wskazał, iż art. 70 Konstytucji RP zawiera w istocie dwa kompleksy norm. Przepis ten statuuje rozliczne zadania państwa w zakresie oświaty i nauki, z którymi nie wiąże się jednak możliwość skierowania roszczenia o ich wyegzekwowanie na rzecz jednostki. Realizacja tych zadań stanowi natomiast gwarancję instytucjonalną dla podmiotowego prawa do nauki, mającego konstytucyjną genezę i konstytucyjnie regulowane fragmenty reżimu normatywnego, co jest objęte drugim kompleksem

${ }^{31}$ M. Markowska, Glosa do wyroku WSA z dnia 5 grudnia 2013 r., VIII SA/Wa 713/13, „Palestra" 2016, t. 6, nr 122; zob. też R. Raszewska-Skałecka, Edukacja osób niepełnosprawnych jako dobro wspólne na tle rozważań administracyjnoprawnych, "Przegląd Prawa Administracji” 2016, t. 105, nr 119; por. L. Garlicki, Komentarz do art. 70, s. 7.

32 Por. wyroki TK: z 8 XI 2000 r., sygn. SK 18/99, OTK ZU 2000, nr 7, poz. 258, oraz z 2 VII 2002 r., sygn. U 7/01, OTK ZU 2002, nr 4/A, poz. 48.

${ }^{33}$ Wyrok TK z 26 IV 2004 r., sygn. K 50/02, OTK ZU 2004, nr 4/A, poz. 32.

${ }^{34}$ Wyrok TK z 16 I 2007 r., sygn. U 5/06, OTK ZU 2007, nr 1/A, poz. 3. 
norm zawartych w art. 70 Konstytucji RP. Powszechny i równy dostęp do wykształcenia stanowi podmiotowe prawo konstytucyjne.

W wyroku z 13 listopada 2007 r. (sygn. P 42/06) ${ }^{35}$ Trybunał Konstytucyjny wskazał, że art. 70 ust. 4 Konstytucji RP traktować należy nie tylko jako przepis programowy albo gwarancyjny wobec ogólnego prawa do nauki (art. 70 ust. 1 Konstytucji RP), ale także jako źródło bardziej szczegółowego prawa podmiotowego - prawa do równego dostępu do mechanizmów wyrównywania przez państwo szans edukacyjnych. Rozstrzygające znaczenie, w ocenie Trybunału, mają tu osobiste właściwości osób uprawnionych do nauki, z których najważniejsze wymienione są $\mathrm{w}$ art. 70 ust. 4 Konstytucji RP. Zgodnie $\mathrm{z}$ tym przepisem o pomoc tę mogą ubiegać się obywatele Polski (co należy uznać za standard minimalny, a nie konstytucyjny zakaz przyznawania tej pomocy cudzoziemcom), będący uczniami lub studentami (niezależne od poziomu nauczania i rodzaju szkoły), którzy ze względu na swoją sytuację osobistą nie mają równego dostępu do wykształcenia. Szczegółowe warunki jej udzielania (w tym kryteria oceny sytuacji osób ubiegających się o nią) powinny być określone ustawą (art. 70 ust. 4 zd. ostatnie Konstytucji RP) w zgodzie z powyższymi wytycznymi konstytucyjnymi.

W kolejnym orzeczeniu ${ }^{36}$ Trybunał podkreślił, że "warunki” udzielania pomocy finansowej i organizacyjnej dla uczniów powinny być określone w ustawie. Jest to zresztą uzasadnione, jak wskazał, materią wspomnianej tu regulacji, wyznaczającej zakres konstytucyjnego prawa podmiotowego, jakim pozostaje prawo do uzyskania pomocy finansowej ze strony władz publicznych w zakresie gwarantującym powszechność i równość dostępu do wykształcenia (zgodnie z postanowieniem art. 70 ust. 1 Konstytucji RP). Powinność ta zaistniała $z$ chwilą wejścia w życie Konstytucji z 1997 r., tj. od 17 października 1997 r. Nakaz unormowania wskazanej w cytowanym przepisie materii w drodze ustawy oznacza jednocześnie zakaz uregulowania jej w akcie niższego rzędu.

Przedmiotem analizy Trybunału Konstytucyjnego w kolejnym orzeczeniu, z 5 listopada 2013 r. ${ }^{37}$, były zakwestionowane przepisy Ustawy z dnia 27 lipca 2005 r. Prawo o szkolnictwie wyższym ${ }^{38}$ (art. 184 ust. 4 i 5). Odnosiły się one do dwóch kategorii studentów. Pierwszą z nich tworzyli studenci, którzy równolegle studiowali co najmniej dwa kierunki

\footnotetext{
${ }^{35}$ Dz.U. 2007 Nr 221, poz. 1649.

${ }^{36}$ Wyrok TK z 26 IV 2004 r., sygn. K 50/02, Dz.U. 2004 Nr 109, poz. 1161.

${ }^{37}$ Wyrok TK z 5 XI 2013 r., sygn. K 40/12, OTK-A 2013, nr 8, poz. 120.

${ }^{38}$ Dz.U. 2005 Nr 164, poz. 1365.
} 
i osiągając wysoką średnią ocen, mogli otrzymywać stypendium tylko na jednym kierunku (art. 184 ust. 4 ustawy). Drugą kategorię stanowili studenci, którzy po ukończeniu jednego kierunku studiów kontynuowali naukę na drugim kierunku (art. 184 ust. 5 ustawy) i nie uzyskiwali prawa do stypendium rektora dla najlepszych studentów, mimo że nie korzystali wcześniej z tej formy pomocy stypendialnej. Trybunał uznał, iż powołane regulacje są zgodne $\mathrm{z}$ art. 32 ust. $1 \mathrm{w}$ zw. z art. 2 i art. 70 ust. 4 Konstytucji RP. Występujące na gruncie art. 184 ust. 4 ustawy zróżnicowanie podmiotów podobnych jest, zdaniem Trybunału, usprawiedliwione. Wskazane kryterium (liczba studiowanych kierunków) spełnia w dostatecznym stopniu wymogi przesądzające o dopuszczalności wprowadzenia wyjątku od zasady równości. Obowiązkiem władz publicznych w świetle art. 70 ust. 4 Konstytucji RP, jak wskazał Trybunał, jest zapewnienie powszechnego i równego dostępu do wykształcenia. W tym właśnie celu są tworzone systemy pomocy indywidualnej dla studentów. Okoliczność ukończenia jednego kierunku studiów zwalnia władze publiczne $\mathrm{z}$ obowiązku dalszego wspierania lub nagradzania za szczególne osiągnięcia osób, które zdecydowały się kontynuować naukę na kolejnym kierunku studiów. Odmienne ich potraktowanie, w porównaniu z osobami, które nie zdobyły jeszcze wyższego wykształcenia, jest zgodne z celem przepisów regulujących formy pomocy państwa dla studentów. Ukończenie studiów przez obywatela prowadzi do osiągnięcia celu, jakim było umożliwienie zdobycia wykształcenia i do wypełnienia obowiązku wynikającego z art. 70 ust. 4 Konstytucji RP. W takim wypadku, zdaniem Trybunału, uznać należy, że państwo wywiązało się z obowiązku wskazanego w art. 70 ust. 4 Konstytucji RP w trakcie studiów na pierwszym (ukończonym) kierunku.

W kolejnym orzeczeniu, z 5 czerwca 2014 r. ${ }^{39}$, przedmiotem analizy Trybunału była ocena konstytucyjności przepisów Ustawy z dnia 27 lipca 2005 r. Prawo o szkolnictwie wyższym w zakresie dotyczącym m.in. możliwości pobierania przez uczelnie publiczne opłat za świadczone usługi edukacyjne związane z kształceniem studentów na studiach stacjonarnych, jeżeli są to studia na drugim lub kolejnym kierunku studiów w formie stacjonarnej. Trybunał wskazał, że prawo do nauki na poziomie wyższym jest współcześnie jednym z najpoważniejszych praw gwarantowanych jednostkom przez państwo. Państwo nie jest w stanie zagwarantować realizacji konstytucyjnych praw i wolności ekonomicznych, socjalnych i kulturalnych na poziomie wyższym niż

\footnotetext{
${ }^{39}$ Wyrok TK z 5 VI 2014 r., sygn. K 35/11, OTK-A 2014, nr 6, poz. 61.
} 
wynikający z możliwości budżetowych. Za niedopuszczalne jednak, zdaniem Trybunału, uznać należy usprawiedliwianie wszelkich ograniczeń tych praw i wolności z powołaniem się na argumenty finansowe, gdyż w ten sposób dałoby się ograniczyć niemal wszystkie gwarancje przyznane jednostkom przez ustawę zasadniczą. Konkludując, Trybunał wskazał, że zwolnienie z opłat za drugi kierunek jedynie najwybitniejszych studentów - jako nagroda za szczególne osiągnięcia - czy tym bardziej wykluczenie zwolnień opłat za kolejny kierunek narusza istotę uprawnienia do bezpłatnego studiowania.

W wyroku z 22 czerwca 2015 r. $^{40}$ Trybunał uznał, że art. 9c ust. 2a Ustawy z dnia 7 września 1991 r. o systemie oświaty ${ }^{41}$ w zakresie, w jakim wyłącza skargę do sądu administracyjnego na unieważnienie egzaminu maturalnego z powodu stwierdzenia niesamodzielnego rozwiązywania zadań egzaminacyjnych przez zdającego podczas sprawdzania arkuszy egzaminacyjnych, jest zgodny z art. 45 ust. 1 Konstytucji RP. W uzasadnieniu Trybunał wskazał, że proces oceniania, rozumiany jako ustalanie stanu faktycznego, nie mieści się w pojęciu "sprawy” W rozumieniu art. 45 ust. 1 Konstytucji RP, procedura sądowa nie jest odpowiednia do weryfikacji prawidłowości unieważnienia pracy z powodu niesamodzielności rozwiązywania zadań stwierdzonej w toku sprawdzania prac, stanowiącej składnik wyniku egzaminu. Uznanie "wyniku egzaminu” za "sprawę" w rozumieniu konstytucyjnym przenosiłoby ciężar decyzyjny $\mathrm{w}$ odniesieniu do procesu diagnozowania wiedzy abiturienta i samodzielności jego pracy z odpowiednio przeszkolonych i nadzorowanych $\mathrm{w}$ procesie ewaluacji egzaminatorów na sąd. Dla prawidłowego diagnozowania stanu wiedzy abiturienta konieczne jest, zdaniem Trybunału, posiadanie odpowiedniego zasobu specjalistycznej wiedzy i doświadczenia pedagogicznego oraz przestrzeganie wspólnego standardu dokonywania ocen prac egzaminacyjnych. Istotne znaczenie w powołanym zakresie ma profesjonalne działanie organów egzaminacyjnych, które ze względów merytorycznych i organizacyjnych są przygotowane do weryfikacji stanu wiedzy abiturienta i samodzielności rozwiązywania przez niego zadań. Po zbadaniu sprawy samodzielności pracy przez właściwe organy egzaminacyjne, wyjaśnieniach złożonych przez zdających egzamin, rozstrzygnięcie dyrektora CKE o upoważnieniu jest ostateczne i nie służy na nie skarga do sądu administracyjnego. Wolą ustawodawcy, jak wskazał Trybunał, było utrzymanie zasady, że unieważnienie

\footnotetext{
${ }^{40}$ Wyrok TK z 22 VI 2015 r., sygn. SK 29/13, OTK-A 2015, nr 6, poz. 83.

${ }^{41}$ Dz.U. 2004 Nr 256, poz. 2572 ze zm.
} 
arkusza egzaminacyjnego z powodu niesamodzielności rozwiązania go stwierdzonej ex post ma charakter czynności technicznej i nie podlega kontroli sądowo-administracyjnej ${ }^{42}$.

W kolejnym wyroku, z 23 lutego 2017 r. ${ }^{43}$, Trybunał wskazał, że art. 29 ust. 4 pkt 4 Ustawy z dnia 27 lipca 2001 r. o służbie zagranicznej ${ }^{44} \mathrm{w}$ zakresie, w jakim pomija zwrot opłat za naukę dzieci, które ze względu na szczególne warunki państwa przyjmującego nie mają możliwości uczęszczania do bezpłatnego przedszkola publicznego, oddziału przedszkolnego przy publicznej szkole podstawowej lub korzystania z innej formy wychowania przedszkolnego w celu realizacji obowiązkowego rocznego przygotowania przedszkolnego, jest niezgodny $\mathrm{z}$ art. 70 ust. 2 zd. 1 i art. 70 ust. 4 zd. $1 \mathrm{w}$ zw. z art. 32 ust. 1 Konstytucji RP. W ocenie Trybunału regulacja powyższa narusza zasadę równego traktowania w dostępie do edukacji, a przez to także ogólną zasadę równości. Przygotowanie przedszkolne jest elementem systemu oświaty i rozpoczyna proces edukacji, a co za tym idzie, nie można tego etapu wyłączać z systemu gwarancji konstytucyjnych wynikających z art. 70 Konstytucji RP.

W dniu 17 października 2017 r. Trybunał Konstytucyjny postanowi1 ${ }^{45}$, $\mathrm{w}$ trybie art. 35 ust. 1 Ustawy z dnia 30 listopada 2016 r. o organizacji i trybie postępowania przed Trybunałem Konstytucyjnym ${ }^{46}$, przedstawić Sejmowi Rzeczypospolitej Polskiej uwagi dotyczące celowości podjęcia działań ustawodawczych zmierzających do uregulowania kwestii zwrotu kosztów przejazdu niepełnosprawnego ucznia i opiekuna do placówek oświatowych. W uzasadnieniu Trybunał wskazał, że nieuregulowanie warunków realizacji zadania gminy dotyczącego zwrotu kosztów przejazdu oznacza, iż w systemie prawnym brakuje norm, których wprowadzenie jest, wynikającym z przepisów Konstytucji, obowiązkiem prawodawcy. Ich adresatem są rodziny wychowujące dzieci niepełnosprawne, do których odnosi się pojęcie rodzin znajdujących się w trudnej sytuacji społecznej. W świetle art. $69 \mathrm{i}$ art. 71 ust. 1 Konstytucji RP niezbędne jest uregulowanie powołanej kwestii w celu wyrównania szans edukacyjnych, w sposób zapewniający wszystkim podmiotom podobnym równy dostęp do tego rodzaju formy pomocy władz publicznych.

\footnotetext{
${ }^{42}$ Pięciu sędziów Trybunału Konstytucyjnego złożyło zdania odrębne.

${ }^{43}$ Wyrok TK z 23 II 2017 r., sygn. K 2/15, OTK-A 2017, poz. 9.

${ }^{44}$ Dz.U. 2017, poz. 161.

${ }^{45}$ Wyrok TK z 17 X 2017 r., sygn. S 1/17, OTK-A 2017, poz. 66.

${ }^{46}$ Dz.U. 2016, poz. 2072.
} 


\section{Prawo do nauki w ustawodawstwie zwykłym}

Konkretyzacją postanowień konstytucyjnych w zakresie prawa do nauki są regulacje ustawowe. Do najważniejszych z nich należy zaliczyć Ustawę z dnia 14 grudnia 2016 r. Prawo oświatowe ${ }^{47}$, Ustawę z dnia 7 września 1991 r. o systemie oświaty ${ }^{48}$ oraz Ustawę z dnia 26 stycznia 1982 r. - Karta Nauczyciela ${ }^{49}$. Ustawa z dnia 7 września 1991 r. o systemie oświaty była jedną z najczęściej nowelizowanych ustaw. Obszerne nowelizacje wprowadzające, oprócz zmian, wiele regulacji o charakterze przejściowym i epizodycznym skutkowały brakiem jej przejrzystości i powodowały konieczność uchwalenia nowego aktu prawnego o znaczeniu systemowym w obszarze oświaty.

Nowa ustawa Prawo oświatowe objęła swoim zakresem część materii regulowanych dotychczas przez ustawę o systemie oświaty. Zawarto w niej również nowe rozwiązania dotyczące ustroju szkolnego i związanych z nim organizacji i funkcjonowania szkół oraz placówek oświatowych.

\subsection{Założenia ogólne systemu oświaty}

Ustawa z dnia 14 grudnia 2016 r. Prawo oświatowe poprzedzona została preambuła, w której wskazano, że oświata w Rzeczypospolitej Polskiej stanowi wspólne dobro całego społeczeństwa, kieruje się zasadami zawartymi w Konstytucji Rzeczypospolitej Polskiej, a także wskazaniami zawartymi w Powszechnej Deklaracji Praw Człowieka, Międzynarodowym Pakcie Praw Obywatelskich i Politycznych oraz Konwencji o Prawach Dziecka.

Nauczanie i wychowanie, zgodnie z preambuła, respektuje chrześcijański system wartości i za podstawę przyjmuje uniwersalne zasady etyki. Kształcenie i wychowanie ma służyć rozwijaniu u młodzieży poczucia odpowiedzialności, miłości Ojczyzny oraz poszanowaniu dla polskiego dziedzictwa kulturowego, przy jednoczesnym otwarciu się na wartości kultur Europy i świata. Rolą szkoły, wskazaną w preambule ustawy, ma być zapewnienie każdemu uczniowi warunków niezbędnych do jego

\footnotetext{
${ }^{47}$ Dz.U. 2017, poz. 59.

${ }^{48}$ Tekst jedn. Dz.U. 2016, poz. 1943.

${ }^{49}$ Tekst jedn. Dz.U. 2017, poz. 1189.
} 
rozwoju, przygotowania go do wypełniania obowiązków rodzinnych i obywatelskich w oparciu o zasady solidarności, demokracji, tolerancji, sprawiedliwości i wolności. Preambuła, chociaż nie zawiera konkretnej treści normatywnej, świadczy o znaczeniu ustawy i może stanowić źródło wskazówek dla jej wykładni teleologicznej ${ }^{50}$. Podkreśla doniosły charakter oświaty rozumianej jako podstawowa potrzeba społeczna, jak również odpowiedzialność państwa za funkcjonowanie systemu oświaty.

System oświaty obejmuje m.in. przedszkola, szkoły (podstawowe, ponadpodstawowe, artystyczne), placówki oświatowo-wychowawcze, placówki kształcenia ustawicznego, placówki artystyczne, poradnie psychologiczno-pedagogiczne, młodzieżowe ośrodki wychowawcze, młodzieżowe ośrodki socjoterapii, specjalne ośrodki szkolno-wychowawcze oraz specjalne ośrodki wychowawcze dla dzieci i młodzieży wymagających stosowania specjalnej organizacji nauki, metod pracy i wychowania, placówki zapewniające opiekę i wychowanie uczniom w okresie pobierania nauki poza miejscem stałego zamieszkania, placówki doskonalenia nauczycieli, biblioteki pedagogiczne, kolegia pracowników służb społecznych. System oświaty jest wspierany przez organizacje pozarządowe, w tym organizacje harcerskie, a także osoby prawne prowadzące statutową działalność w zakresie oświaty i wychowania (art. 2 ustawy).

System oświaty, w rozumieniu art. 1 ustawy, ma za zadanie w szczególności realizację prawa każdego obywatela Rzeczypospolitej Polskiej do kształcenia się oraz prawa dzieci i młodzieży do wychowania i opieki, odpowiednich do wieku i osiągniętego rozwoju, a także wspomaganie przez szkołę wychowawczej roli rodziny.

Wychowanie rozumiane jest jako wspieranie dziecka w rozwoju ku pełnej dojrzałości w sferze fizycznej, emocjonalnej, intelektualnej, duchowej i społecznej, wzmacniane i uzupełniane przez działania z zakresu profilaktyki problemów dzieci i młodzieży. Jego celem jest m.in. kształtowanie u uczniów postaw prospołecznych, upowszechnianie wiedzy i umiejętności niezbędnych do aktywnego uczestnictwa w kulturze, sztuce narodowej i światowej, upowszechnianie wśród dzieci i młodzieży wiedzy o zasadach zrównoważonego rozwoju, kształtowanie u uczniów postaw przedsiębiorczości i kreatywności sprzyjających aktywnemu uczestnictwu w życiu gospodarczym.

${ }^{50}$ L. Morawski, Zasady wykładni prawa, Toruń 2006, s. 139. 
Treści, metody oraz organizacja nauczania mają być dostosowane do możliwości psychofizycznych uczniów, z możliwością zapewnienia korzystania z pomocy psychologiczno-pedagogicznej i specjalnych form pracy dydaktycznej.

Szczególną opieką i ochroną mają być objęte dzieci i młodzież niepełnosprawna, niedostosowana społecznie i zagrożona niedostosowaniem społecznym, której należy zapewnić możliwość pobierania nauki we wszystkich typach szkól, zgodnie $z$ indywidualnymi potrzebami rozwojowymi i edukacyjnymi oraz predyspozycjami. System oświaty zapewnia również opiekę nad uczniami niepełnosprawnymi przez umożliwianie realizowania zindywidualizowanego procesu kształcenia, form i programów nauczania oraz zajęć rewalidacyjnych, a także nad uczniami szczególnie uzdolnionymi poprzez umożliwianie realizowania indywidualnych programów nauczania oraz ukończenia szkoły każdego typu w skróconym czasie ${ }^{51}$. Podobnie opieką mają być objęci uczniowie pozostający w trudnej sytuacji materialnej i życiowej.

System oświaty ma zagwarantować możliwość zakładania i prowadzenia szkół i placówek przez różne podmioty; kierunki i treści kształcenia mają być dostosowane do wymogów rynku pracy, a uczniowie przygotowani do wyboru zawodu i kierunku kształcenia.

\subsection{Organizacja nauczania}

Szkoła i placówka, w myśl przepisów ustawy Prawo oświatowe, może być szkołą i placówką publiczną albo niepubliczną, może być zakładana i prowadzona przez jednostkę samorządu terytorialnego, inną osobę prawną, jak również osobę fizyczną (art. 8 ustawy).

Szkoła publiczną jest szkoła, która: zapewnia bezpłatne nauczanie w zakresie ramowych planów nauczania, przeprowadza rekrutację uczniów w oparciu o zasadę powszechnej dostępności, zatrudnia nauczycieli posiadających kwalifikacje określone w odrębnych przepisach (art. 14 ustawy).

Szkoła podstawowa może być tylko szkołą publiczną lub niepubliczną o uprawnieniach szkoły publicznej (art. 17 ustawy).

Ustawa wprowadza podział szkół publicznych i niepublicznych na: ośmioletnią szkołę podstawową oraz szkoły ponadpodstawowe, do

${ }^{51}$ Zob. R. Raszewska-Skałecka, op. cit. 
których zalicza czteroletnie liceum ogólnokształcące, pięcioletnie technikum, trzyletnią branżową szkołę I stopnia, trzyletnią szkołę specjalną przysposabiającą do pracy, dwuletnią branżową szkołę II stopnia, szkołę policealną dla osób posiadających wykształcenie średnie lub wykształcenie średnie branżowe, o okresie nauczania nie dłuższym niż 2,5 roku (art. 18 ustawy).

Minister właściwy do spraw oświaty i wychowania koordynuje i realizuje politykę oświatową państwa i współdziała w tym zakresie z wojewodami oraz z innymi organami i jednostkami organizacyjnymi właściwymi w sprawach funkcjonowania systemu oświaty. Do jego zadań należy również sprawowanie nadzoru pedagogicznego nad szkołami i placówkami. Przy ministrze właściwym do spraw oświaty i wychowania może działać Krajowa Rada Oświatowa, będąca społecznym organem opiniodawczym i wnioskodawczym w sprawach oświaty (art. 43 ustawy).

Działalnością szkoły lub placówki kieruje i reprezentuje ją na zewnątrz dyrektor. Do jego zadań należy również sprawowanie nadzoru pedagogicznego, opieki nad uczniami oraz stwarzanie warunków harmonijnego rozwoju psychofizycznego poprzez aktywne działania prozdrowotne, realizowanie uchwał rady szkoły lub placówki oraz rady pedagogicznej, podjętych w ramach ich kompetencji stanowiących, dysponowanie środkami określonymi w planie finansowym szkoły lub placówki zaopiniowanym przez radę szkoły lub placówki i ponoszenie odpowiedzialności za ich prawidłowe wykorzystanie (art. 68 ustawy). Wskazana regulacja określa zakres zadań i kompetencji dyrektora szkoły (placówki) oraz obszar jego odpowiedzialności.

Zgodnie z Ustawą z dnia 26 stycznia 1982 r. - Karta Nauczyciela dyrektor jest przełożonym służbowym wszystkich pracowników szkoły. Sprawuje opiekę nad dziećmi i młodzieżą uczącą się w szkole. Jest on w szczególności odpowiedzialny za: dydaktyczny i wychowawczy poziom szkoły, realizację zadań zgodnie z uchwałami rady pedagogicznej i rady szkoły, podjętymi w ramach ich kompetencji stanowiących, oraz zarządzeniami organów nadzorujących szkołę. Tworzy warunki do rozwijania samorządnej i samodzielnej pracy uczniów i wychowanków, zapewnia pomoc nauczycielom $w$ realizacji ich zadań i ich doskonaleniu zawodowym, zapewnia w miarę możliwości odpowiednie warunki organizacyjne do realizacji zadań dydaktycznych i opiekuńczo-wychowawczych, czuwa także nad bezpieczeństwem uczniów i nauczycieli w czasie zajęć organizowanych przez szkołę (art. 7 ustawy). 
W szkole lub placówce zatrudniającej co najmniej trzech nauczycieli działa rada pedagogiczna, która jest kolegialnym organem szkoły lub placówki w zakresie realizacji jej statutowych zadań dotyczących kształcenia, wychowania i opieki. Przewodniczaccym rady pedagogicznej jest dyrektor szkoły lub placówki. W szkołach i placówkach działają rady rodziców, do których zadań należy reprezentowanie ogółu rodziców uczniów (art. 69 i 83 ustawy).

\subsection{Obowiązek szkolny}

Rozwinięcie przepisów konstytucyjnych w zakresie obowiązku nauki do ukończenia 18. roku życia stanowi art. 35 i n. ustawy Prawo oświatowe.

Ustawa przewiduje, że nauka jest obowiązkowa do ukończenia 18. roku życia. Obowiązek nauki w szerszym, konstytucyjnym znaczeniu zawiera w sobie pojęcie obowiązku szkolnego, czyli obowiązku zdobywania wiedzy i umiejętności w sposób zorganizowany - w formach szkolnych ${ }^{52}$. Obowiązek szkolny dziecka rozpoczyna się z początkiem roku szkolnego w roku kalendarzowym, w którym dziecko kończy siedem lat, oraz trwa do ukończenia szkoły podstawowej, nie dłużej jednak niż do ukończenia 18. roku życia. Spełnia się go przez uczęszczanie do szkoły podstawowej publicznej albo niepublicznej. Po ukończeniu szkoły podstawowej obowiązek nauki realizowany jest przez: uczęszczanie do publicznej lub niepublicznej szkoły ponadpodstawowej lub realizowanie, zgodnie $z$ odrębnymi przepisami, przygotowania zawodowego u pracodawcy. Obowiązek szkolny może być realizowany również poprzez uczęszczanie odpowiednio do przedszkola lub szkoły za granica lub przy przedstawicielstwie dyplomatycznym innego państwa w Polsce. Za spełnianie obowiązku szkolnego i obowiązku nauki, o którym mowa $\mathrm{w}$ art. 31 ust. 4 (obowiązkowe roczne przygotowanie przedszkolne w przedszkolu, oddziale przedszkolnym w szkole podstawowej lub innej formie wychowania przedszkolnego w odniesieniu do dziecka, które ukończyło sześć lat), uznaje się też udział dzieci i młodzieży $\mathrm{z}$ niepełnosprawnością intelektualną $\mathrm{w}$ stopniu głębokim $\mathrm{w}$ zajęciach rewalidacyjno-wychowawczych. W odniesieniu do dzieci posiadających orzeczenie o potrzebie kształcenia specjalnego, o których mowa $\mathrm{w}$ art. 31 ust. 2 ustawy, rozpoczęcie spełniania obowiązku szkolnego

\footnotetext{
${ }^{52}$ M. Pilich, Ustawa o systemie ośziaty. Komentarz, Warszawa 2015, s. 313 i n.
} 
może być odroczone nie dłużej niż do końca roku szkolnego w roku kalendarzowym, w którym dziecko kończy dziewięć lat. O odroczeniu orzeka dyrektor publicznej szkoły podstawowej, w obwodzie której dziecko mieszka, na wniosek rodziców.

Realizowanie przez dziecko obowiązku szkolnego spoczywa w pierwszej kolejności na rodzicach (opiekunach prawnych) dziecka. W myśl przepisów ustawy Prawo oświatowe rodzice dziecka podlegającego obowiązkowi szkolnemu są obowiązani do dopełnienia czynności związanych ze zgłoszeniem dziecka do szkoły, zapewnienia regularnego uczęszczania dziecka na zajęcia szkolne, jak również zapewnienia dziecku warunków umożliwiających przygotowywanie się do zajęć (art. 40 ustawy).

Dyrektorzy publicznych szkół podstawowych kontrolują spełnianie obowiązku szkolnego przez dzieci zamieszkałe w obwodach tych szkół, a gmina kontroluje spełnianie obowiązku nauki przez młodzież zamieszkałą na terenie tej gminy, w tym m.in. prowadzą ewidencję spełniania obowiązku szkolnego oraz obowiązku nauki. Wójt gminy (burmistrz, prezydent miasta) jest obowiązany przekazywać dyrektorom publicznych szkół podstawowych na obszarze gminy informacje o aktualnym stanie i zmianach w ewidencji dzieci i młodzieży w wieku 3-18 lat (art. 41 ustawy).

Niespełnianie obowiązku, o którym mowa w art. 31 ust. 4 ustawy Prawo oświatowe (roczne przygotowanie przedszkolne), obowiązku szkolnego lub obowiązku nauki podlega egzekucji w trybie przepisów o postępowaniu egzekucyjnym w administracji. Przez niespełnienie tego obowiązku należy rozumieć nieusprawiedliwioną nieobecność w okresie jednego miesiąca na co najmniej 50\% dniach zajęć (art. 42 ustawy).

Z obowiązkiem nauki i obowiązkiem szkolnym ścisłe związane są obowiązki dziecka-ucznia. Ustawa Prawo oświatowe przewiduje, że obowiązki ucznia określa się w statucie szkoły. W szczególności w powołanej regulacji uwzględnieniu podlegają obowiązki w zakresie:

- właściwego zachowania podczas zajęć edukacyjnych,

- usprawiedliwiania, w określonym terminie i formie, nieobecności na zajęciach edukacyjnych, w tym formy usprawiedliwiania nieobecności przez osoby pełnoletnie,

- przestrzegania zasad ubierania się uczniów na terenie szkoły lub noszenia na terenie szkoły jednolitego stroju - w przypadku, o którym mowa w art. 100 ustawy, 
- przestrzegania warunków wnoszenia i korzystania z telefonów komórkowych i innych urządzeń elektronicznych na terenie szkoły,

- właściwego zachowania wobec nauczycieli i innych pracowników szkoły oraz pozostałych uczniów (art. 99 ustawy).

\subsection{Prawa dziecka-ucznia - wybrane zagadnienia}

Prawa ucznia to podstawowe prawa człowieka-dziecka rozpatrywane w relacji uczeń - władze szkolne na gruncie konkretnej rzeczywistości oświatowej.

\subsubsection{Prawo do podmiotowego traktowania w procesie dydaktyczno-wychowawczym}

Człowiek ma pewne nierozerwalnie związane ze swoją naturą prawa, które starsze są od istnienia państwa. Prawo wewnętrzne i międzynarodowe ich nie tworza, ale jedynie przyczyniają się do ich ochrony i afirmacji. Takim prawem - pierwotnym w stosunku do państwa - jest prawo do poszanowania godności, które szczególnego znaczenia nabiera w relacjach uczeń-nauczyciel. Podstawowym kryterium oceny rzeczywistości szkolnej $\mathrm{w}$ aspekcie przestrzegania praw dziecka jest szacunek do godności ucznia, którego proceduralne gwarancje winny być w sposób jasny określone ${ }^{53}$.

Nie ulega wątpliwości, że szkoła jest drugim po domu rodzinnym środowiskiem, które ma zapewnić warunki do prawidłowego rozwoju psychofizycznego dziecka ${ }^{54}$. Stres towarzyszący procesowi edukacyjnemu i nierozłącznie z nim związany stanowi niezbędny środek motywacyjny. W nadmiarze jednak, w szczególności jeżeli jego źródłem są nieprawidłowe relacje nauczyciel-uczeń, prowadzi do powstawania poważnych zaburzeń w zachowaniu uczniów, które w znacznym stopniu utrudniają, a nawet uniemożliwiają osiągnięcie celów leżących u podstaw procesu dydaktyczno-wychowawczego.

${ }^{53}$ J. Stadniczeńko, Prawo dziecka do nauki - prawa w oświacie, w: Konwencja o prawach dziecka. Wybór zagadnień (artykuły i komentarze), pod red.S.L. Stadniczeńki, Warszawa 2015, s. 167; zob. też M. Chodorowska, Prawa dziecka-ucznia jednym z podstawowych komponentów wychowania podmiotowego, w: Dziecko w kręgu wychowania, pod red. B. Jodłowskiej, Kraków 2002, s. 215-224.

${ }^{54}$ B. Czeredrecka, Szkoła jako źródło zaburzeń w zachowaniu uczniów, w: Prawa dziecka. Deklaracje i rzeczywistość, pod red. J. Bińczyckiej, Warszawa 1993, s. 249. 
W myśl ustawy Prawo oświatowe nauczyciel w swoich działaniach dydaktycznych, wychowawczych i opiekuńczych ma obowiązek kierowania się dobrem uczniów, troską o ich zdrowie, postawę moralną i obywatelska, z poszanowaniem godności osobistej ucznia (art. 5 ustawy $)^{55}$. Nauczyciel jako pracownik szkoły wykonuje przynależną jej część władztwa pedagogicznego i jest bezpośrednio odpowiedzialny za spoczywające na niej zadania opiekuńcze, dydaktyczne i wychowawcze. Powierzone mu obowiązki winien wykonywać przede wszystkim dla dobra uczniów i z uwzględnieniem jak najlepiej pojętego interesu ucznia. Zgodnie z ustawą o systemie oświaty nauczyciel jest obowiązany indywidualizować pracę $\mathrm{z}$ uczniem na zajęciach edukacyjnych, jak również dostosować wymagania edukacyjne odpowiednio do potrzeb rozwojowych i edukacyjnych oraz możliwości psychofizycznych ucznia (art. 43c ustawy). Ustawa o systemie oświaty przewiduje również możliwość zwolnienia ucznia z realizacji niektórych obowiązkowych zajęć edukacyjnych ze względu na stan zdrowia, specyficzne trudności w uczeniu się, niepełnosprawność, posiadane kwalifikacje lub zrealizowanie danych obowiązkowych zajęć edukacyjnych na wcześniejszym etapie edukacyjnym, przyznając takie uprawnienie dyrektorowi szkoły (art. $44 \mathrm{~d}$ ustawy o systemie oświaty).

Prawa i obowiązki nauczycieli przedszkoli, szkół i placówek określa również Ustawa z dnia 26 stycznia 1982 r. - Karta Nauczyciela. Zgodnie z jej postanowieniami nauczyciel obowiązany jest:

- rzetelnie realizować zadania związane z powierzonym mu stanowiskiem oraz podstawowymi funkcjami szkoły: dydaktyczna, wychowawczą i opiekuńcza, w tym zadania związane z zapewnieniem bezpieczeństwa uczniom w czasie zajęć organizowanych przez szkołę;

- wspierać każdego ucznia w jego rozwoju;

- dążyć do pełni własnego rozwoju osobowego;

- kształcić i wychowywać młodzież w umiłowaniu ojczyzny, w poszanowaniu Konstytucji Rzeczypospolitej Polskiej, w atmosferze wolności sumienia i szacunku dla każdego człowieka;

- dbać o kształtowanie u uczniów postaw moralnych i obywatelskich zgodnie z ideą demokracji, pokoju i przyjaźni między ludźmi różnych narodów, ras i światopoglądów (art. 6 ustawy).

${ }_{55}$ Zob. K. Jadach, Odpowiedzialność prawna nauczycieli za bezpieczeństwo dziecka w placówce oświatowej - zarys problemu, „Studia Prawnicze i Administracyjne” 2017, t. 20, nr 2, s. 11 i n. 


\subsubsection{Prawo do jawnej i umotywowanej oceny postępów w nauce}

Zasady oceniania, klasyfikowania i promowania uczniów w szkołach publicznych określone zostały w ustawie o systemie oświaty (ar. 44a i n). Regulują one ważną sferę z zakresu systemu oświaty i związane są bezpośrednio $z$ realizacją konstytucyjnego prawa do nauki ${ }^{56}$. Zgodnie z zapisami ustawy ocenianiu podlegają osiągnięcia edukacyjne ucznia oraz zachowanie ucznia. Ustawa $\mathrm{w}$ art. $44 \mathrm{~b}$ wprowadza podział oceniania na odnoszące się do osiągnięć edukacyjnych oraz zachowania. Kryteria oceniania na wskazanych obszarach różnią się, stąd też oba rodzaje ocen nie mają na siebie zasadniczego wpływu ${ }^{57}$.

Ocenianie osiągnięć edukacyjnych ucznia polega na rozpoznawaniu przez nauczycieli poziomu i postępów w opanowaniu przez ucznia wiadomości i umiejętności. Punktem odniesienia są wymagania określone w podstawie programowej kształcenia ogólnego lub efekty kształcenia określone w podstawie programowej kształcenia w zawodach oraz wymagania edukacyjne wynikające $\mathrm{z}$ realizowanych w szkole programów nauczania.

Ocenianie zachowania ucznia polega na rozpoznawaniu przez wychowawcę oddziału, nauczycieli oraz uczniów danego oddziału stopnia respektowania przez ucznia zasad współżycia społecznego i norm etycznych oraz obowiązków określonych w statucie szkoły. Ocenianie osiągnięć edukacyjnych i zachowania ucznia odbywa się w ramach oceniania wewnątrzszkolnego. Ma ono na celu w szczególności:

- informowanie ucznia o poziomie jego osiągnięć edukacyjnych i jego zachowaniu oraz o postępach w tym zakresie;

- udzielanie uczniowi pomocy w nauce poprzez przekazanie informacji o tym, co zrobił dobrze i jak powinien się dalej uczyć;

- udzielanie wskazówek do samodzielnego planowania własnego rozwoju;

- motywowanie ucznia do dalszych postępów w nauce i zachowaniu;

- dostarczanie rodzicom i nauczycielom informacji o postępach i trudnościach w nauce i zachowaniu ucznia oraz o szczególnych uzdolnieniach ucznia;

- umożliwienie nauczycielom doskonalenia organizacji i metod pracy dydaktyczno-wychowawczej (art. 44b ustawy). Taki sposób oceniania

\footnotetext{
${ }^{56}$ Zob. wyrok TK z 24 IX 2013 r., sygn. K 35/12, OTK-A 2013, nr 7, poz. 94.

${ }^{57}$ M. Pilich, op. cit., s. 756-757.
} 
pozwala nauczycielowi na rozpoznanie poziomu i postępów ucznia, a jemu samemu na poprawę procesu uczenia się poprzez uzyskanie wyczerpujących informacji o poziomie jego osiągnięć.

$\mathrm{W}$ trakcie nauki w szkole uczeń otrzymuje oceny bieżące oraz klasyfikacyjne (śródroczne i roczne, a w szkole policealnej - semestralne oraz końcowe). Oceny są jawne dla ucznia i jego rodziców, a nauczyciel zobowiązany jest do uzasadnienia ustalonej oceny w sposób określony w statucie szkoły. Również sprawdzone i ocenione pisemne prace ucznia są udostępniane uczniowi i jego rodzicom, co ma istotne znaczenie, warunkując możliwość poprawienia wyników w nauce. Ustawa przewiduje także możliwość złożenia zastrzeżenia do dyrektora szkoły przez ucznia lub jego rodziców w sytuacji uznania, że roczna ocena klasyfikacyjna z zajęć edukacyjnych lub roczna ocena klasyfikacyjna zachowania zostały ustalone niezgodnie z przepisami dotyczącymi trybu ustalania tych ocen (art. 44e i n. ustawy).

\subsubsection{Prawo do wpływania na życie szkoły poprzez działalność samorządową}

Prawo do wpływania na życie szkoły przez działalność samorządową określone zostało w ustawie Prawo oświatowe (art. 85 i n.). Zgodnie z jej treścią w szkole i placówce działa samorząd uczniowski, który tworzą wszyscy uczniowie szkoły lub placówki. Samorząd uczniowski jest obligatoryjnym organem w strukturze szkoły, a jego rolą jest kształtowanie poczucia odpowiedzialności uczniów za sprawy publiczne i demokratyzację życia placówki. Zasady wybierania i działania organów samorządu określa regulamin uchwalany przez ogół uczniów w głosowaniu równym, tajnym i powszechnym. Organy samorządu są jedynymi reprezentantami ogółu uczniów. Ustawa zastrzega, że postanowienia regulaminu samorządu nie mogą pozostawać w sprzeczności ze statutem szkoły lub placówki.

Ustawa wyposażyła samorząd uczniowski w prawo do przedstawiania radzie szkoły lub placówki, radzie pedagogicznej oraz dyrektorowi wniosków i opinii we wszystkich sprawach szkoły lub placówki, w szczególności dotyczących realizacji podstawowych praw uczniów, takich jak:

- prawo do zapoznawania się z programem nauczania, z jego treścia, celem i stawianymi wymaganiami,

- prawo do jawnej i umotywowanej oceny postępów w nauce i zachowaniu, 
- prawo do organizacji życia szkolnego, umożliwiające zachowanie właściwych proporcji między wysiłkiem szkolnym a możliwością rozwijania i zaspokajania własnych zainteresowań,

- prawo redagowania i wydawania gazety szkolnej,

- prawo organizowania działalności kulturalnej, oświatowej, sportowej oraz rozrywkowej zgodnie z własnymi potrzebami i możliwościami organizacyjnymi w porozumieniu $\mathrm{z}$ dyrektorem,

- prawo wyboru nauczyciela pełniącego rolę opiekuna samorządu.

Samorząd w porozumieniu z dyrektorem szkoły lub placówki może również podejmować działania z zakresu wolontariatu.

\subsubsection{Wolność sumienia i wyznania oraz prawo do uznania i zachowania tożsamości narodowej}

Prawo do nauki obejmuje swoim zakresem prawo do nauczania moralnego i religijnego, pozostając w ścisłym związku z gwarantowaną konstytucyjnie wolnością sumienia i wyznania. Nadto warunkiem koniecznym do rozwoju jednostki i korzystania przez nią w pełni z przysługujących jej praw, w tym prawa do nauki, jest związek z własną narodową kulturą (językiem, literatura, historią) $)^{58}$.

W ustawie o systemie oświaty przewidziano możliwość organizowania w publicznych przedszkolach oraz szkołach podstawowych nauki religii na życzenie rodziców. W publicznych szkołach ponadpodstawowych nauka religii może być organizowana na życzenie bądź rodziców, bądź samych uczniów. Po osiągnięciu pełnoletności o pobieraniu nauki religii decydują uczniowie. Nauka religii w założeniu ustawy jest więc dobrowolna - obejmuje osoby zainteresowane jej pobieraniem. $Z$ art. 12 ustawy korespondują przepisy Konstytucji RP: art. 25 (zasada bezstronności państwa w sprawach religijnych, światopoglądowych i filozoficznych), art. 48 ust. 1 (prawo rodziców do wychowania dzieci zgodnie z własnymi przekonaniami) oraz art. 53 (wolność sumienia i wyznania).

Warunki i sposób wykonywania przez szkoły wskazanych zadań określa w drodze rozporządzenia minister właściwy do spraw oświaty i wychowania w porozumieniu z władzami Kościoła katolickiego i Polskiego Autokefalicznego Kościoła Prawosławnego oraz innych Kościołów i związków wyznaniowych (art. 12 ustawy).

\footnotetext{
${ }^{58}$ J. Mikosz, op. cit., s. 1003.
} 
Ustawodawca zobligował również szkołę i placówkę publiczną do umożliwienia uczniom podtrzymywania poczucia tożsamości narodowej, etnicznej, językowej i religijnej, a w szczególności nauki języka oraz własnej historii i kultury (art. 13 ustawy). Pomimo że ustawodawca nie posługuje się pojęciem "mniejszości”, wskazana regulacja koresponduje z Ustawą z dnia 6 stycznia 2005 r. o mniejszościach narodowych i etnicznych oraz o języku regionalnym ${ }^{59}$. Praw wynikających z art. 13 Prawo oświatowe nie powinno się jednak zawężać poprzez przyjęcie, iż odnosi się on jedynie do mniejszości uznanych ustawowo. Dotyczy on bowiem podtrzymywania cechy wyróżniającej grupę osób (kultura, język), dla której w demokratycznym państwie prawnym powinno być miejsce niezależnie od sztywnej i arbitralnej regulacji ustawy o mniejszościach $^{60}$. Na wniosek rodziców nauka we wskazanym zakresie może być prowadzona: w osobnych grupach, oddziałach lub szkołach, w grupach, oddziałach lub szkołach - z dodatkową nauką języka oraz własnej historii i kultury, w międzyszkolnych zespołach nauczania. Warunki i sposób wykonywania przez szkoły i placówki tych zadań, w szczególności minimalną liczbę uczniów, dla których organizuje się poszczególne formy nauczania, określa $\mathrm{w}$ drodze rozporządzenia minister właściwy do spraw oświaty i wychowania.

W pracy dydaktyczno-wychowawczej szkoły publiczne zapewniają podtrzymywanie kultury i tradycji regionalnej. Podręczniki szkolne i książki pomocnicze do kształcenia uczniów w zakresie niezbędnym do podtrzymywania poczucia tożsamości narodowej, etnicznej i językowej mogą być dofinansowywane z budżetu państwa z części, której dysponentem jest minister właściwy do spraw oświaty i wychowania.

\section{Podsumowanie}

Przekazywanie kolejnym pokoleniom dorobku kulturowego stanowi niezbędny warunek rozwoju społeczeństw od początków ich istnienia. Pozbawienie jednostki możliwości edukacji ogranicza jej aktywny udział w życiu danego społeczeństwa, a także korzystanie z osiągnięć cywilizacyjnych i kulturowych.

Analiza kondycji współczesnego człowieka czyni zasadnym sięganie, w szczególności w procesie dydaktycznym, do określonego systemu

\footnotetext{
${ }^{59}$ Tekst jedn. Dz.U. 2017, poz. 823.

${ }^{60}$ M. Pilich, op. cit., s. 267.
} 
wartości ${ }^{61}$. Nauczanie przejawiające się m.in. w kształtowaniu stosunku młodych ludzi do otaczającego świata powinno mieć charakter recepcji twórczej. Przygotowanie ich do odpowiedzialnego kierowania swoim życiem winno przejawiać się nie tylko w wyposażeniu w umiejętności praktyczne, ale również uwrażliwieniu na ogólnoludzkie bogactwo cywilizacji.

Niezwykle istotne znaczenie dla rozwoju społecznego dziecka ma świadomość własnych praw, możliwości i ograniczeń, zasad komunikowania się w grupie, umiejętność rozwiązywania konfliktów bez przemocy, szacunek i tolerancja dla innych oraz kształtowanie poczucia własnej wartości. Stanowią one bez wątpienia fundament prawidłowego procesu edukacyjnego.

Prawo do nauki zalicza się do grupy praw kulturalnych. W odniesieniu do dziecka przyjmuje złożony, wieloaspektowy charakter. W treści tego prawa można wyróżnić wiele elementów składających się na całościowe prawo dziecka do nauki, m.in. cele oświaty, obowiązek nauki, prawa rodziców w procesie edukacji. Pozostaje ono również w ścisłym związku z polegającym na zdobywaniu wiedzy i umiejętności obowiązkiem nauki, któremu towarzyszy węższe pojęcie obowiązku szkolnego sprowadzającego się do konieczności uzyskania wykształcenia na określonym poziomie. Obowiązujące w Polsce regulacje ustawowe i podstawowe, dla których punktem wyjścia są unormowania konstytucyjne, ujmują prawo do nauki jako prawo człowieka, z którego możliwość korzystania winni mieć wszyscy przebywający na terytorium Polski, a którego gwarancjami są powszechny i równy dostęp do wykształcenia oraz systemy indywidualnej pomocy finansowej i organizacyjnej dla uczniów. W odniesieniu do dziecka jako istoty biopsychospołecznie niedojrzałej ustalony zakres ochrony prawnej jest szerszy, w tym w aspekcie zabezpieczenia przed nieodpowiedzialnymi decyzjami osób dorosłych, czego wyrazem jest nałożony konstytucyjnie obowiązek nauki, za którego realizację odpowiedzialność ponoszą rodzice (opiekunowie) małoletniego. Takie ujęcie omawianego prawa pozostaje w zgodności ze standardem międzynarodowym prawa do nauki. Kwestie szczegółowe związane z realizacją prawa, jak również obowiązku nauki, w myśl postanowień konstytucyjnych, spoczywają na ustawodawcy zwykłym. Oprócz gwarancji prawnych oraz pozaprawnych niezwykle istotne są

${ }^{61}$ M. Balcerek, Prawa kulturalne dziecka, w: Konwencja o prawach dziecka a prawo polskie, pod red. A. Lopatki, Warszawa 1991, s. 140. 
mechanizmy kontrolne mające na celu przestrzeganie i realizację wskazanego prawa w praktyce.

Szkoła jest drugim po rodzinie środowiskiem wychowawczym mającym w założeniu wspierać rodziców w ukierunkowaniu i rozwoju dziecka. Istotne znaczenie ma w tym zakresie należyte przygotowanie do zawodu nauczycielskiego, sformułowanie czytelnych kryteriów selekcji, podnoszenie kwalifikacji kadry nauczycielskiej oraz należyte jej wynagradzanie.

Niski poziom kwalifikacji nauczycielskich, zbyt surowa dyscyplina szkolna, nieposzanowanie godności ucznia stanowia, oprócz trudności materialnych rodziny, najczęstszy powód nieregularnego uczęszczania do szkoły, czy też porzucania nauki.

Równie istotne są w omawianym zakresie obowiązujące w szkole jasne i zrozumiałe dla wszystkich członków społeczności szkolnej reguły postępowania. Ich znajomość, a także uświadamianie sobie przez uczniów spoczywających na nich obowiązków oraz przysługujących im praw wraz z przejrzystymi procedurami ich dochodzenia determinuje proces kształcenia i wychowania młodego pokolenia $\mathrm{w}$ atmosferze szacunku dla praw innego człowieka.

\section{THE RIGHT TO EDUCATION. THE RIGHTS OF THE CHILD AND A PUPIL}

\section{Sum mary}

The subject matter of this article was the right to education with a particular regard to the rights of the child being a pupil and his/her right to personal treatment in the teaching and the whole educational process, the right to the open and motivated assessment of the progress in learning, the right to impact the school life via local government activities, as well as the right to the freedom of conscience and religion, and the right to recognise and preserve the national identity in the teaching process. The issue of pupil's responsibilities, and in particular compulsory schooling and compulsory education, have also been raised.

The article defined the right to education and placed it among other acts of international law - the Universal Declaration of Human Rights, the International Covenant on Economic, Social and Cultural Rights, the Convention for the Protection of Human Rights and Fundamental Freedoms, the Declaration of the Rights of the Child, as well as the Convention on the Rights of the Child, known as the World Constitution of the Rights of the Child.

In addition to the nature of the right to education, the subject matter of the consideration was also the principles and guarantees of its implementation, contained in the Basic Law. Their analysis led to the conclusion about the limited nature of 
the right of parents to bring up the child according to their own convictions, the implementation of which should be compatible with the welfare of the child and the constitutionally guaranteed right to receive education. An analysis of the regulations applicable in the prescribed scope statutory, and in particular in terms of universal and equal access to education have also been discussed.

The reflections presented in the article have been enriched with case law examples and judgments delivered by the European Court of Human Rights in Strasbourg, the Supreme Court, and the Common Courts. The analysis of the existing legal references, the doctrine, and the case law has allowed to reach a conclusion on the fundamental nature of the right to education, the implementation of which conditions the development of an individual and the full use of its rights.

Keywords: the right to education - the rights of the child - compulsory education compulsory schooling - the education system 